\title{
FORMATION OF CHLORINATED ORGANICS IN DRINKING WATER OF ISTANBUL (TURKEY) AND SALERNO (ITALY)
}

L. RIZZO ${ }^{1}$

H. SELCUK ${ }^{2}$

A. NIKOLAOU ${ }^{3}$

V. BELGIORNO ${ }^{1}$

M. BEKBOLET ${ }^{4}$

S. MERIC ${ }^{1, *}$

\author{
${ }^{1}$ University of Salerno, Department of Civil Engineering \\ 84084 Fisciano (SA), Italy \\ ${ }_{2}^{2}$ Pamukkale University, Environmental Engineering Department \\ Kinikli-Pamukkale, Turkey \\ ${ }^{3}$ University of the Aegean, Department of Environmental Studies \\ Water and Air Quality Laboratory \\ University Hill, 81100 Mytilene, Greece \\ ${ }^{4}$ Bogazici University, Institute of Environmental Sciences
} 0815 Bebek (Istanbul), Turkey

*to whom all correspondence should be addressed: Tel: +3908996 4016

Received:10/01/05

Accepted: 30/03/05 e-mail: msureyya@unisa.it; smeric@tin.it

\begin{abstract}
The occurrence of THMs and HAAs, and other volatile organics in Istanbul (Turkey) and Salerno (Italy) surface water resources was investigated by the previous and present data obtained on raw, coagulated, pre-chlorinated, pre-ozonated water samples. The present drinking water directives/regulations in developed countries set maximum contaminant level (MCL) for THMs at different levels. In Italy, where the $80-85 \%$ of water demand is supplied by groundwater, a relatively low THMs value of $30 \mathrm{\mu g} \mathrm{I}^{-1}$ was set, however there are no HAAs and bromate limits. On the other hand, there is still no regulation for the THMs in Turkey. The characterization of chlorinated by-products, particularly THMs, is detailed according to raw water origin and treatment technologies currently applied in both cities.
\end{abstract}

KEYWORDS: chlorinated by-products, TTHM formation potential, TTHMs and HAAs, surface water, pre-chlorination, pre-ozonation

\section{INTRODUCTION}

The interaction of chlorine with bromine and organics (e.g., humic and fulvic acids) naturally occurring in raw water, results in chlorinated or brominated disinfection byproducts (DBPs) including trihalomethanes (THMs: chloroform- $\mathrm{CHCl}_{3}$, dichlorobromomethane- $\mathrm{CHCl}_{2} \mathrm{Br}$, dibromochloromethane- $\mathrm{CHBr}_{2} \mathrm{Cl}$, bromofrom- $\mathrm{CHBr}_{3}$ ), haloacetic acids (HAAs), haloacetonitriles (HANs) (Rook, 1974). Among these THMs are the most abundant compounds in chlorinated waters and HAAs concentrations are much lower (Palacios et al., 2000; Villanueva et al., 2003). The occurrence of THMs in finished drinking water is a matter of concern for human health because they are potentially carcinogen compounds (USEPA, 2002).

DBPs levels can vary greatly within a single water supply, depending on both water quality (e.g., total organic carbon (TOC), bromide, $\mathrm{pH}$, temperature, ammonia, carbonate alkalinity) and treatment conditions (e.g., disinfectant dose, contact time, TOC removal before disinfection) (Amy et al., 1987, USEPA, 1998). The THMs formation rate was 
reported to increase with increasing $\mathrm{pH}$ (Krasner et al., 1989) while that of HAAs and total organic halogen (TOX) decreases. Reckhow et al. (1990) showed a linear relationship between chlorine consumption and the activated aromatic content of the various humic and fulvic acids extracted from natural waters.

The control of THMs by reducing organic precursors, commonly expressed as NOM removal, using enhanced/optimized coagulation has a prime relevance (Bell-Ajy et al., 2000, Rizzo et al., 2004). The USEPA (1998) points out enhanced coagulation, joined to granular activated carbon (GAC) adsorption and precipitative softening among the best available technologies (BATs) for THMs control. Meanwhile photocatalysis (Bekbölet and Ozkosemen, 1996; Bekbolet et al., 1996) and photoelectrocatalysis (Selcuk et al., 2003) have become promising advanced oxidation technologies for NOM removal. Among many kinds of semiconductors, $\mathrm{TiO}_{2}$ is the most widely employed catalyst due to its low cost, physical/chemical stability and its ability to mineralize chlorinated by-products precursors such as humic acids (HA) to $\mathrm{CO}_{2}$.

The risks related to THMs formation force the community to look for alternative water sources, treatment methods or disinfectants. As an alternative disinfectant, chlorine dioxide $\left(\mathrm{ClO}_{2}\right)$ is commonly used in preoxidation and disinfection steps of surface water treatment due to low formation of THMs compared to chlorinated water ( $\mathrm{Li}$ et al., 1996; Chang et al., 2000). However, disinfection with $\mathrm{ClO}_{2}$ results in chlorite formation, disinfection by product not yet classifiable as to health effects and, namely, human carcinogenicity (USEPA, 2002). Although typically used as an oxidant, ozone is more effective than chlorine, chlorine dioxide, or chloramines for the inactivation of water-borne pathogens (von Gunten, 2003). Ozone has also some disadvantages which include; (i) increased biodegradable organic carbon (BDOC) (ii) formation of brominated disinfection by-products such as bromate; (iii) not stabile for the protection of the treated water in distribution system; (iv) more expensive and has more technological requirements than chlorination.

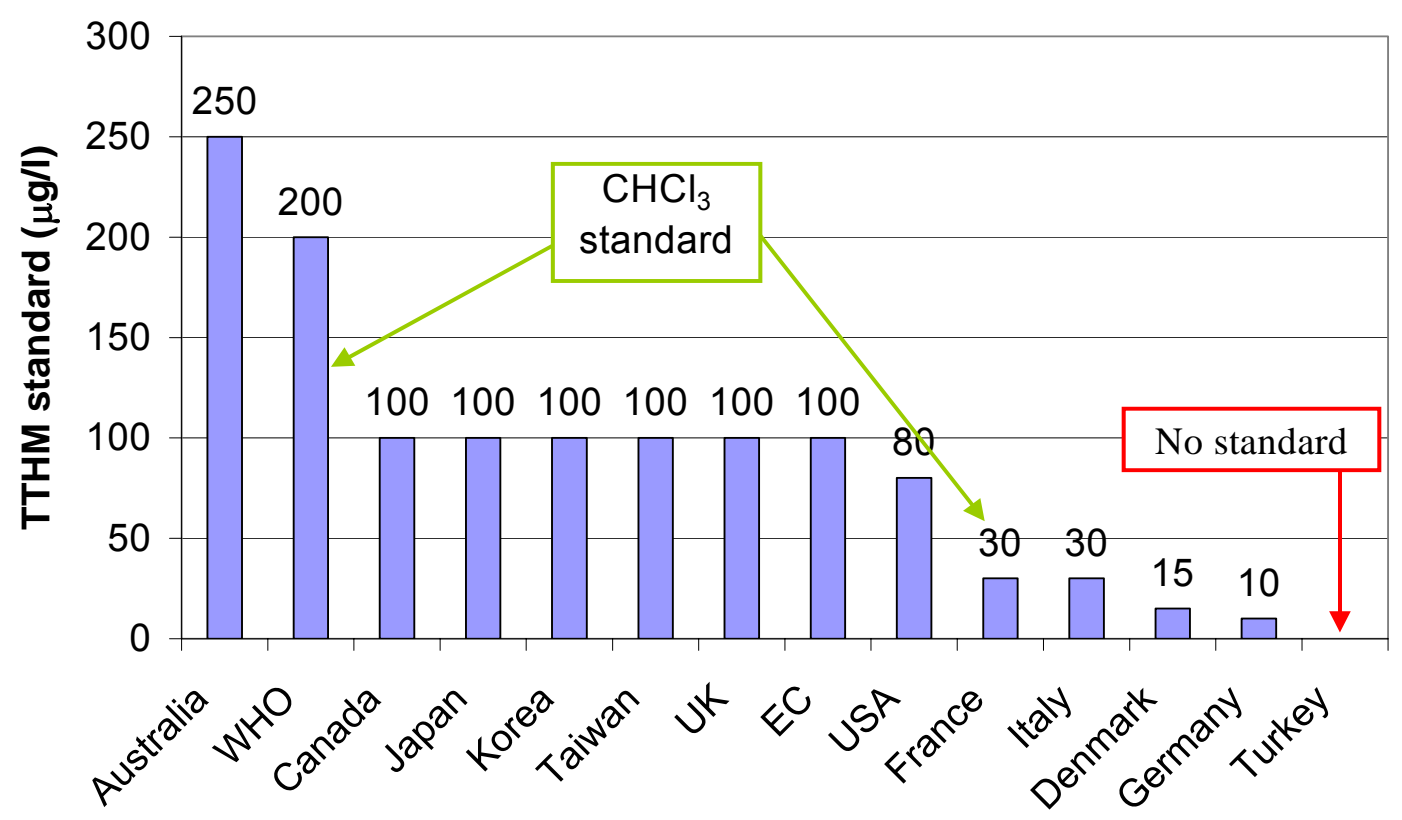

Figure 1. TTHMs standards in different countries

Standards and maximum contaminant level (MCL) for THMs were set at different levels in developed countries (Figure 1). In Italy, having $80-85 \%$ of water demand satisfied by groundwater, a relative lower THMs value of $30 \mathrm{\mu g} \mathrm{I}^{-1}$ was set (Official Journal of Italy, 2001). The drinking water treatment plants using chlorination are in Apulia region 
(Souther Italy) and they asked the Italian Health Ministry for an extension of THMs limit to $60 \mathrm{\mu g} \mathrm{I}^{-1}$ (Official Journal of Italy, 2003). Other extensions were requested by Foggia and Brindisi provinces as $80 \mu \mathrm{g} \mathrm{I}^{-1}$ for Foggia and Brindisi provinces. However, in Turkey no regulation for THMs has been set yet.

This research focused on the evaluation of THMs formation in different water origin from Istanbul (Turkey) and Salerno (Italy). Treatment technologies currently applied and solutions to improve the efficiency in DBPs control are also detailed. Recent data on THMs, HAAs and other organics are presented for the same water resources.

\section{MATERIALS AND METHODS}

\subsection{Sampling and conservation}

The raw and finished samples were taken from Alento constructed basin and Basso Sele ground water resources in summer season (Salerno, Italy). The samples were delivered into the Environmental Analysis Laboratory of Salerno University within $1 \mathrm{~h}$ to be analysed or stored at $4{ }^{\circ} \mathrm{C}$ for further analyses. Previous THMs data for the raw and finished water for Istanbul's water resources were obtained from Istanbul Water and Sewage Works Administration Laboratory (www.ISKI.gov.tr).

The raw water samples taken in June 2004 were chlorinated and after 7 days of incubation, the free chlorine was blocked by thiopentasulpate, than they were transported as cooled to the Environmental Monitoring Laboratory of Aegean University, Greece for being analysed for THMs and HAAs formation potential.

\subsection{Analytical measurements}

Raw and finished samples were filtered through $0.45 \mu \mathrm{m}$ GMF filter $(25 \mathrm{~mm} \mathrm{GD/X}$, Whatman Inc, USA) for DOC and $\mathrm{UV}_{254}$ adsorbance measurements. TOC and DOC were measured by a SHIMADZU analyzer (model 5000A). UV-Vis spectrophotometer was used to measure $U_{254}$ absorbance (PerkinElmer, model Lambda12, USA). THMs were measured by GC-MS (ThermoFinnigan, USA) with column for organohalogenated compounds (Supelco, USA), according to 5710B method (AWWA-APHA-WEF, 1998). pH (Hach Ins, model 9024, USA) and turbidity (Hach Ins, model 2100N) were also monitored.

The THMFP and HAAs-FP measurements of June 2004 samples were performed using a Hewlett Packard Gas Chromatograph (GC) 5890 Series II with a ${ }^{63} \mathrm{Ni}$ Electron Capture Detector (ECD). The carrier gas was $\mathrm{He}$ and the make-up gas $\mathrm{N}_{2}$. The column used was fused silica DB-1, $30 \mathrm{~m} \times 0.32 \mathrm{~mm}$ i.d. $\times 0.25 \mu \mathrm{m}$ film thickness. The injection technique was split/splitless. The applied analytical methods as well as their evaluation have been reported elsewhere (Nikolaou et al, 2002a,b). Recoveries ranged from $87.6 \%$ to $112.8 \%$ for THMFP, from $60.4 \%$ to $144.5 \%$ for the other chlorinated by-products and from $78.1 \%$ to $123.7 \%$ for HAAs-FP. The DLs (estimated for signal-to-noise ratio $3: 1$ ) ranged from $0.005 \mu \mathrm{g} \mathrm{I}^{-1}$ to $0.070 \mu \mathrm{g} \mathrm{I}^{-1}$ for the volatile chlorinated by-products (CBPs) and from 0.01 $\mu \mathrm{gl}^{-1}$ to $0.2 \mu \mathrm{g} \mathrm{I}^{-1}$ for HAAs.

\section{RESULTS AND DISCUSSION}

\subsection{Water resources and characteristics}

\section{Turkey}

Istanbul is divided into two parts by the Bosphorus between the Black Sea and the Sea of Marmara. $65 \%$ of inhabitants of around 12 million lives on the European side while the rest is on the Asiatic side. Total water demand of Istanbul is supplied from Büyükçekmece, Sazlidere and Terkos Lakes in European and Ömerli, Darlik and Elmali reservoirs in Asian sides (Figure 2). Currently water demand is about $1.1^{*} 10^{9} \mathrm{~m}^{3} \mathrm{y}^{-1}$ and it was estimated as 2.195 mil. $\mathrm{m}^{3} \mathrm{y}^{-1}$ for 2020 (Selcuk et al., 2004). Average water quality is classified slightly polluted in Darlik, polluted in Terkos, Buyukcekmece and Alibeykoy and 
high polluted in Elmali reservoir (Table 1). Poor water quality in the most of reservoirs is attributed to the urban settlement, industries and farms in the catchment areas (Selcuk et al., 2004) in the catchment areas.

Buyukcekmece treatment plant consists of pre-chlorination using chlorine gas while in Omerli treatment plant pre-ozonation is applied. Table 2 shows the chemicals used at the treatment plants.

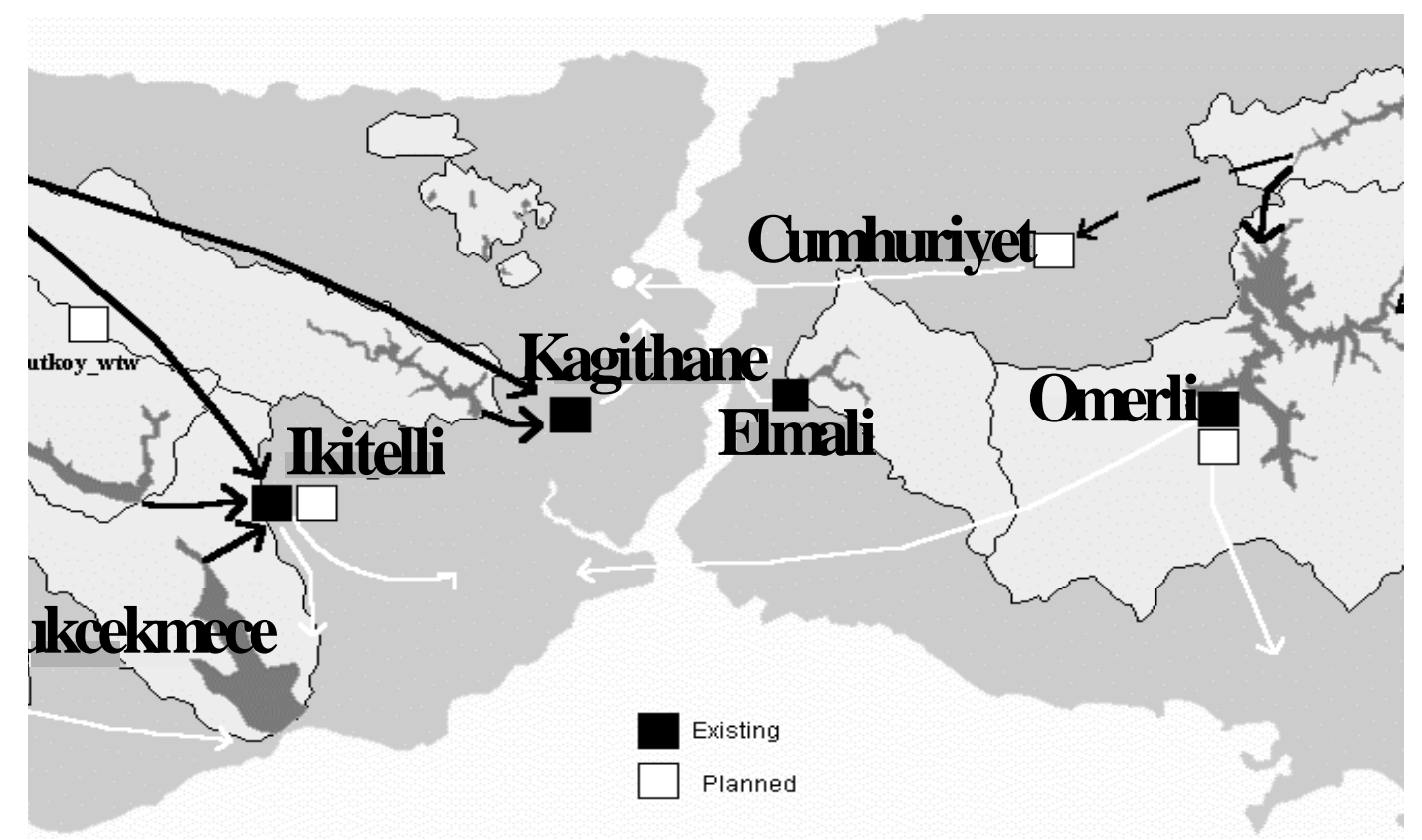

Figure 2. Location of the sampling point and water treatment plants in Istanbul, Turkey

Table 1. Capacities and basic characteristics of water treatment plants in Istanbul

\begin{tabular}{|c|c|c|c|c|c|}
\hline \multirow[t]{2}{*}{ Plant } & \multirow[t]{2}{*}{ Symbol } & \multirow[t]{2}{*}{$\begin{array}{c}\text { Treated water } \\
\text { in } 2000\left(\mathrm{~m}^{3}\right)\end{array}$} & \multicolumn{2}{|c|}{$\begin{array}{l}\text { Turbidity } \\
\text { (NTU) }\end{array}$} & \multirow{2}{*}{$\begin{array}{c}\text { TOC } \\
\left(\mathrm{mg} \mathrm{l}^{-1}\right)\end{array}$} \\
\hline & & & Raw water & Treated water & \\
\hline Ömerli & WTP1 & 301541881 & $3.1(1.2-5.51)^{1}$ & $0.5(0.3-0.6)$ & $3.0-3.5$ \\
\hline Kağıthane & WTP2 & 158091572 & $11.6(6.9-20)$ & $0.8(0.6-1.1)$ & $2.8-4.2$ \\
\hline Ikitelli & WTP3 & 83582300 & $3(2.6-3.8)$ & $0.3(0 . .3-0.5)$ & $3.0-4.2$ \\
\hline $\begin{array}{l}\text { B. } \\
\text { Cekmece }\end{array}$ & WTP4 & 67260287 & $3(2-4.5)$ & $0.4(0.27-0.6)$ & $2.7-4.4$ \\
\hline $\begin{array}{l}\text { Elmalı } \\
\text { TOTAL }\end{array}$ & WTP5 & $\begin{array}{c}4702352 \\
615178392\end{array}$ & $6.9(2-20.9)$ & $0.9(0.5-1.3)$ & $3.5-5.5$ \\
\hline
\end{tabular}

minimum and maximum values measured.

Table 2. Chemicals used in water treatment plants in Istanbul for the year 2000.

\begin{tabular}{|c|c|c|c|c|c|c|c|c|c|}
\hline \multirow[t]{2}{*}{ Plant } & \multicolumn{2}{|c|}{ Alum } & \multicolumn{2}{|c|}{$\mathrm{Cl}_{2}$} & \multirow{2}{*}{$\begin{array}{c}\text { Poly } \\
\left(\mathrm{kg} \mathrm{y}^{-1}\right)\end{array}$} & \multirow{2}{*}{$\begin{array}{c}\text { PAC } \\
\left(\mathrm{kg} \mathrm{y}^{-1}\right)\end{array}$} & \multicolumn{2}{|c|}{$\mathrm{O}_{3}$} & \multirow{2}{*}{$\begin{array}{c}\text { Hypoch. } \\
\left(\mathrm{kg} \mathrm{y}^{-1}\right)\end{array}$} \\
\hline & $\left(\mathrm{kg} \mathrm{y}^{-1}\right)$ & $\left(\mathrm{mg} \mathrm{l}^{-1}\right)$ & $\left(\mathrm{kg} \mathrm{y}^{-1}\right)$ & $\left(\mathrm{mg} \mathrm{l}^{-1}\right)$ & & & $\left(k y^{-1}\right)$ & $\left(\mathrm{mg} \mathrm{l}^{-1}\right)$ & \\
\hline WTP1 & 9107380 & 27 & 2025208 & 6.7 & 45400 & & & & \\
\hline WTP2 & 4385114 & 26 & 627042 & 4 & -- & & In part & & 1785 \\
\hline WTP3 & 2600726 & 30 & 212165 & 2.5 & 8361 & & $\begin{array}{c}12374 \\
0\end{array}$ & 1.4 & \\
\hline WTP4 & 1833945 & 23 & 343235 & 5.1 & 3813 & & & & \\
\hline WTP5 & 349750 & 71 & 26068 & 5.5 & -- & 3275 & 1996 & 0.4 & \\
\hline
\end{tabular}


Italy

The annual report of the Italian Environmental Protection Agency (APAT, 2003) shows that the use of groundwater resources increased from $80 \%$ to $85 \%$ between the years 1993-1998.

Particularly, in several coastal areas with great tourist vocation the population can increase from 3 to 10 times mainly in southern Italy, thus water requirement can be only satisfied by integrative treated surface water. Figure 3 shows the location of the water treatment plant constructed in Alento basin which was main concern of this study. In Figure 3, the schematic presentation of the existing treatment plant is also shown. The Alento constructed basin has a capacity of $26^{*} 10^{6} \mathrm{~m}^{3} \mathrm{y}^{-1}$ and its $7.3 \cdot 10^{6} \mathrm{~m}^{3} \mathrm{y}^{-1}$ part can be used to produce drinking water in summer season. The treatment plant consists of preoxidation with $\mathrm{ClO}_{2}$, on line coagulation with polyaluminium chloride (PACl) addition, filtration and final disinfection with the use of $\mathrm{ClO}_{2}$ (Figure 3).

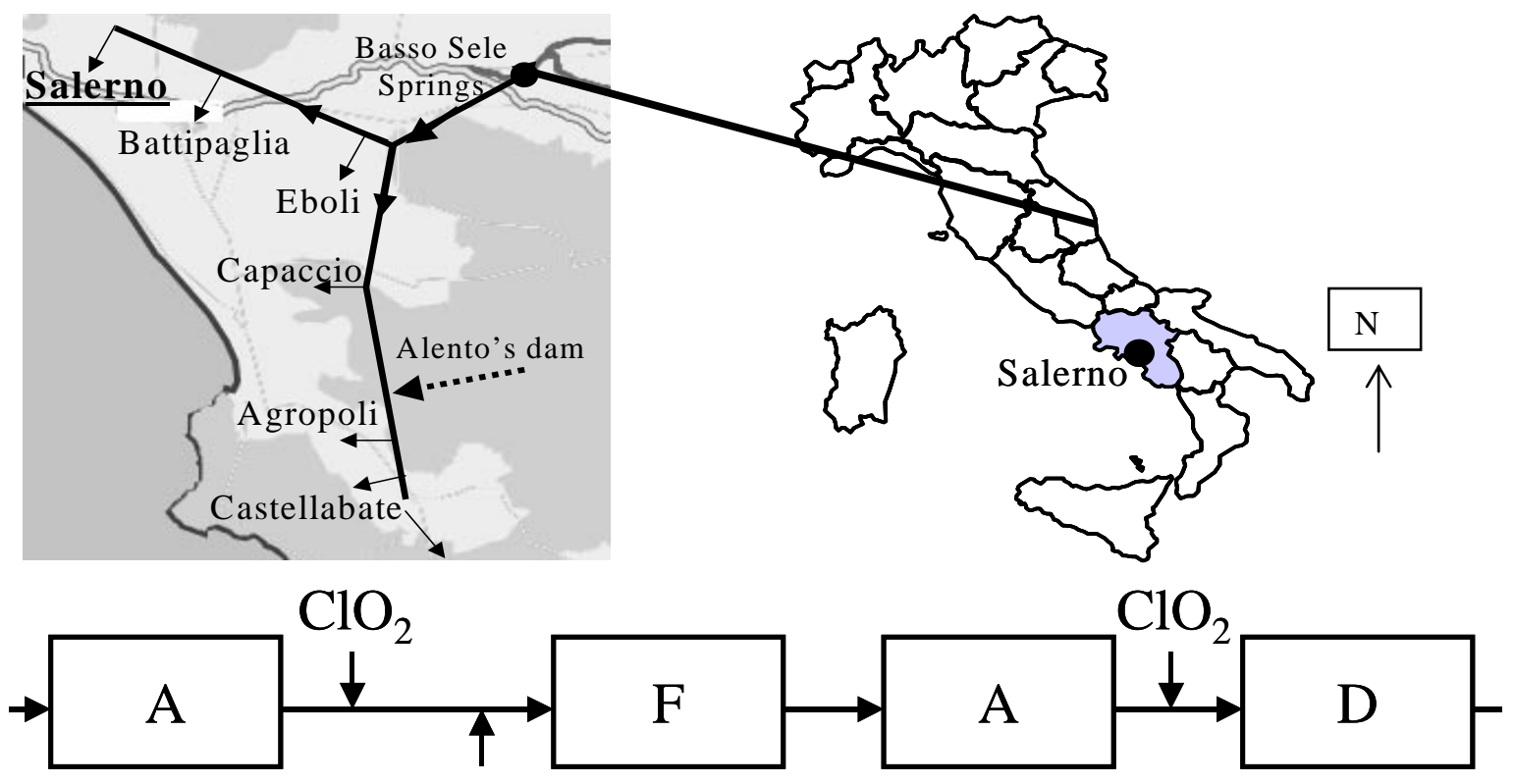

PACl

Figure 3. Schematic representation of the water system in the province of Salerno, Italy

The characteristics of some water resources used in the province of Salerno are presented in Table 3.

Table 3. Water characteristic of some drinking water sources in Salerno province

\begin{tabular}{llcccccccc}
\hline Resource & Type & $\begin{array}{c}\mathrm{T} \\
\left({ }^{\circ} \mathrm{C}\right)\end{array}$ & $\mathrm{pH}$ & $\begin{array}{c}\text { Alk } \\
\left(\mathrm{mg} \mathrm{l}^{-1}\right)^{*}\end{array}$ & $\begin{array}{c}\mathrm{Br}^{-1} \\
\left(\mathrm{mgl}^{-1}\right)\end{array}$ & $\begin{array}{c}\mathrm{NO}_{3}^{-} \\
\left(\mathrm{mg} \mathrm{l}^{-1}\right)\end{array}$ & $\begin{array}{c}\mathrm{TOC} \\
\left(\mathrm{mg} \mathrm{l}^{-1}\right)\end{array}$ & $\begin{array}{c}\mathrm{DOC} \\
\left(\mathrm{mg} \mathrm{l}^{-1}\right)\end{array}$ & $\begin{array}{c}\mathrm{UV}_{254} \\
\left(1 \mathrm{~cm}^{-1}\right)\end{array}$ \\
\hline Alento (SA) & CB & 18.6 & 7.66 & 192.5 & - & - & $2.8-4$ & 2.96 & - \\
Basso Sele & $\mathrm{SW}$ & 13.7 & 7.14 & 303.3 & 0.19 & 0.9 & 0.20 & & 0.002 \\
W1 (Eboli) & $\mathrm{GW}$ & 14.2 & & & 0.06 & 2.62 & & 0.079 \\
W2 (Eboli) & WW & 16.7 & 7.13 & & 0.016 & 6 & & 0.011 \\
W3 (Eboli) & WW & 11.6 & 6.3 & & 0.12 & 0.59 & & 0.001 \\
W4 (Eboli) & WW & 15.2 & 7.17 & & 0.06 & 19.2 & & & 0.010 \\
W5 (Eboli) & WW & 15.2 & 7.01 & & 0.07 & 8.38 & & & 0.004 \\
\hline
\end{tabular}

\footnotetext{
*as $\mathrm{mg} \mathrm{CaCO}_{3} \mathrm{I}^{-1}$; CB: constructed basin; SW: spring water; GW: groundwater; WW: well water
} 
The Basso Sele (SA) springs have a flow rate of $1,600 \mathrm{I} \mathrm{s}^{-1}$ and continuously being used to supply water to 50 municipalities in Salerno province. Due to high water quality only disinfection with sodium hypochlorite $\left(0.2-0.4 \mathrm{mg} \mathrm{Cl}_{2} \mathrm{I}^{-1}\right)$ is applied as treatment.

\subsection{THMs in raw and finished water}

\section{Turkey}

The THMs concentrations detected in November 1999 in finished water of some Istanbul water treatment plants are shown in Figure 4. The use of pre-ozonation in Elmali treatment plant (WTP5b) resulted in the average 65\% reduction of THMs formation. The average TTHMs concentration in finished water from Buyukcekmece plant (WTP4) was above USEPA limit $\left(80 \mu \mathrm{g} \mathrm{I}^{-1}\right)$. The formation of TTHMFPs varied depending on the nature of the water and treatment process efficiency; i.e. in the case of chlorine preoxidation in Elmali, chloroform $\left(\mathrm{CHCl}_{3}\right)$ was the dominant specie while the percent of brominated species in total TTHMFPs increased in the case of ozone pre-oxidation although their concentrations were lower than the case of chlorine pre-oxidation. Although no pre-ozonation is used, by the fact that its bromide concentration is high (> $\left.275 \mu \mathrm{g} \mathrm{I}^{-1}\right), \mathrm{CHBr}_{2} \mathrm{Cl}$ was the major THMs specie followed by $\mathrm{CHBrCl}_{2}$ and $\mathrm{CHCl}_{3}$ in Buyukcekmece plant.

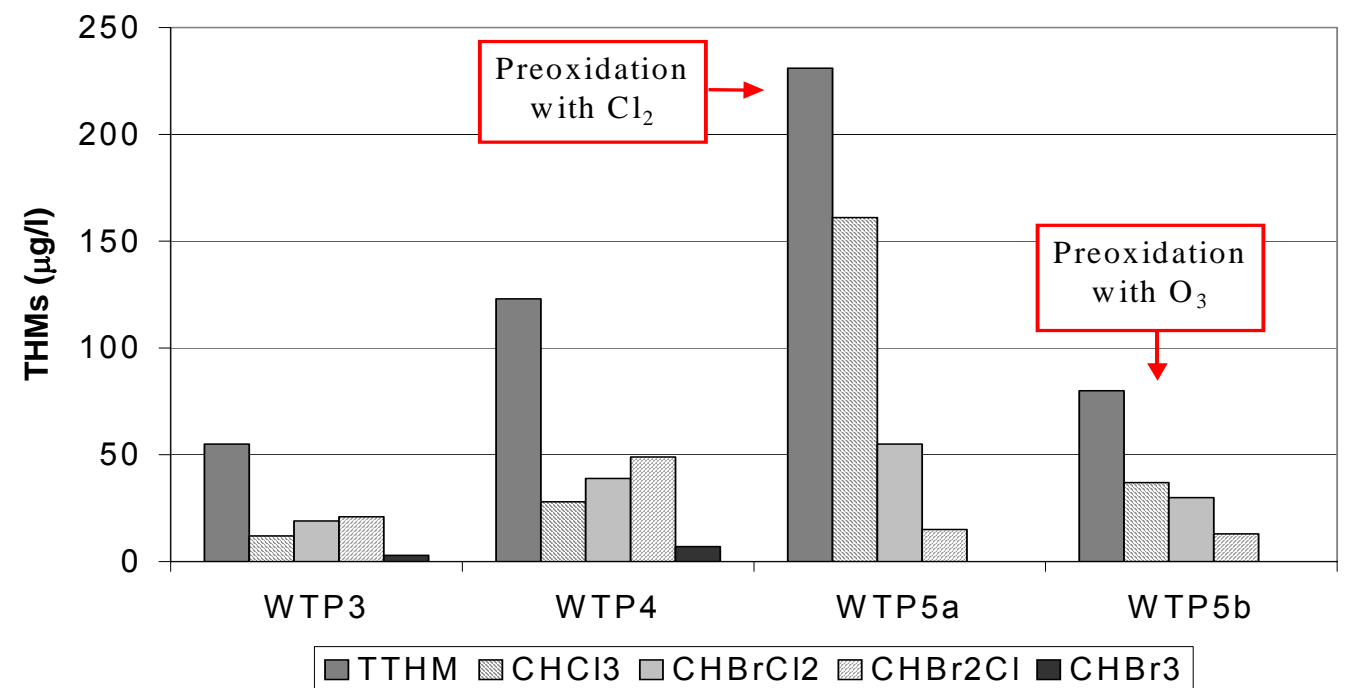

Figure 4. TTHMs in Istanbul water treatment plants

Figure 5 shows the monthly average variations in TTHMs in finished water of the treatment plants of Istanbul for the period of March 2002-Febrauary 2004. According to those results, TTHMs level in Buyukcekmece and Elmali (ozone pre-oxidation) finished water decreased approximately $50 \%$ due to improvements in coagulation process and decreased final chlorine dose used. The highest levels of TTHMs were observed in Buyukcekmece and Kagithane finished water. There was around $50 \%$ of difference in TTHMs of the treatment plants between winter and summer seasons. These results were in accordance with the previous studies (Gallard and Gunten, 2002).

\section{Italy}

The average TTHMFPs of raw water of Alento basin were measured as $234 \mathrm{~g} \mathrm{I} \mathrm{I}^{-1}$ for water characteristics varied from 3-4 $\mathrm{mg} \mathrm{I}^{-1}$ of TOC, 2.7-2.9 $\mathrm{mg} \mathrm{I}^{-1}$ of DOC, 2-3 I (mg-m $)^{-1}$ of specific $U_{254}$ absorbance $\left(S_{U V A}{ }_{254}\right.$ ) and $190 \mathrm{mg}$ as $\mathrm{CaCO}_{3} \mathrm{I}^{-1}$ of alkalinity. Bromide concentration was below detection limit. As well as the high level of TTHMFPs $\left(>150 \mu \mathrm{g} \mathrm{I}^{-1}\right)$ in raw water, ratios of the dominant species in total amount was more interesting because the brominated species are still under suspicions of the carcinogenicity studies (Lily et al., 1994; USEPA, 2002). The water treatment decreased TOC and TTHMFPs 
levels at 20 and $35 \%$, respectively. However, due to high chlorite formation in the effluent, the improvement of organic THMs precursors removal by jar test was evaluated with the aim of replacing $\mathrm{ClO}_{2}$ with $\mathrm{Cl}_{2}$. By using $\mathrm{PACl}$ dose up to $30-35 \mathrm{mg} \mathrm{Al}_{2} \mathrm{O}_{3} \mathrm{I}^{-1} \mathrm{TOC}$ removal was enhanced at $20 \%$ and TTHMFPs was reduced to less than $30 \mathrm{\mu g} \mathrm{I}^{-1}$ (Rizzo et al., 2004).

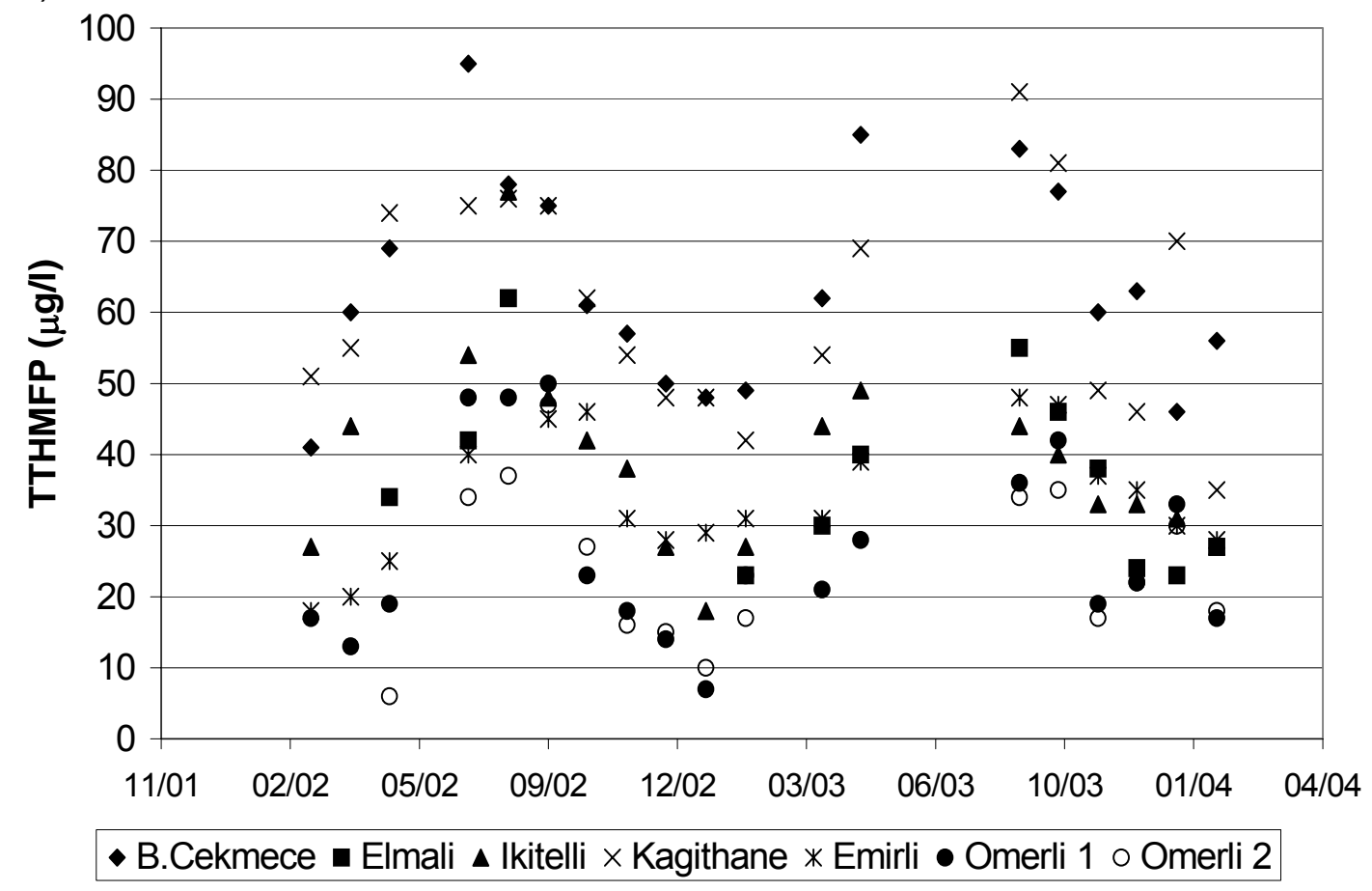

Figure 5. THMFPs of TTHMs in water resources of Istanbul between 2002 and 2004

TTHMFPs, (SP) level of Basso Sele springs (SPW) and the water from wells were measured much lower (25-109 $\left.\mathrm{g} \mathrm{I} \mathrm{I}^{-1}\right)$ than Alento basin. The groundwater with too low NOM content, measured as TOC and $U_{254}$ (Table 3), contributed to hold low TTHMs formation risk. However, the groundwater yielded the highest concentrations of brominated species, particularly $\mathrm{CHBr}_{3}$, and almost no chloroform formation (SPW, WW3, WW4). The spectra of the species formed are to be studied by integrating with the toxicological studies (Teuschler and Simmons, 2003).

\subsection{TTHMFPs and HAA-FPs and other volatile organics measurements in raw water samples}

The raw water characteristics of the June 2004 samples taken from Omerli and Buyukcekmece (Istanbul) and Alento (Salerno) water resources are given in Table 4. Buyukcekmece and Alento basin characteristics seemed to be similar in terms of $U_{254}$ and alkalinity with the exception of bromide concentration which was high in the Buyukcekmece water sample.

In chlorinated raw water samples by $20 \mathrm{mg} \mathrm{I}^{-1}$ of $\mathrm{Cl}_{2}$, many chlorinated and other volatile organics were detected as presented in Table 5. THMs and HAAs were the most abundant substances, while the other CBPs (haloacetonitriles, haloketones) except chloral hydrate occurred at much lower concentrations. In terms of THMs, the order of the magnitude among the water samples was Buyukcekmece $\left(159.4 \mu \mathrm{g} \mathrm{I}^{-1}\right)>$ Omerli $(128.5$ $\left.\mu \mathrm{g} \mathrm{I}^{-1}\right)>$ Alento $\left(75.6 \mu \mathrm{g} \mathrm{I}^{-1}\right)$. 
Table 4. Water characteristics of June 2004 samples

\begin{tabular}{lcccc}
\hline Parameter & Unit & Omerli & Buyukcekmece & Alento \\
\hline Alkalinity & $\left(\mathrm{mg} \mathrm{l}^{-1}\right)$ & 70 & 150 & 194.4 \\
Turbidity & $(\mathrm{NTU})$ & 2.7 & 3.2 & 2.5 \\
UV $_{254}$ & $\left(1 \mathrm{~m}^{-1}\right)$ & 0.97 & 0.1 & 0.1 \\
TOC & $\left(\mathrm{mg} \mathrm{l}^{-1}\right)$ & 3.05 & 3.61 & $\mathrm{Nm}$ \\
Bromide & $\left(\mu \mathrm{g} \mathrm{I}^{-1}\right)$ & 95 & 274 & $\mathrm{Nd}$ \\
Chloride & $\left(\mathrm{mg} \mathrm{l}^{-1}\right)$ & 45 & 98 & 14 \\
Alluminum & $\left(\mathrm{mg} \mathrm{l}^{-1}\right)$ & $\mathrm{Nm}$ & $\mathrm{Nm}$ & 0.025 \\
Iron & $\left(\mathrm{mg} \mathrm{l}^{-1}\right)$ & $\mathrm{Nm}$ & $\mathrm{Nm}$ & 0.172 \\
pH & -- & 7.18 & 7.65 & 7.33 \\
\hline
\end{tabular}

Nm: not measured

For the present water characteristics the distribution of the species changed with respect to the previous findings. For instance, in Omerli $\mathrm{CHCl}_{3}$ was detected at higher level than brominated species while dibromochloromethane was the dominant specie and the brominated species were formed at considerable levels in Buyukcekmece water which has the highest level of bromide $\left(0.274 \mathrm{mg} \mathrm{l}^{-1}\right)$. Neither Omerli nor Alento samples yielded bromoform at detectable level.

On the contrary, Alento sample exhibited the highest total HAAs concentrations, especially trichloroacetic acid (TCA, $137.7 \mathrm{~g} \mathrm{I}^{-1}$ ), followed by dichloroacetic acid (DCA, $\left.72.9 \mu \mathrm{g} \mathrm{I}^{-1}\right)$. TCA and DCA were the most dominant HAAs species for other resources as well (TCA: $19.7 \mu \mathrm{g} \mathrm{I}^{-1}$ and $41.4 \mu \mathrm{g} \mathrm{I}^{-1}$ for Buyukcekmece and Omerli, respectively, DCA: $23.1 \mu \mathrm{g} \mathrm{I}^{-1}$ and $36.6 \mu \mathrm{g} \mathrm{I}^{-1}$ for Buyukcekmece and Omerli, respectively).

Among other volatile DBPs, the major specie was chloral hydrate $(\mathrm{CH})$ which was formed at levels comparable to or higher than THMs species (range 61.3-78.1 $\mathrm{\mu g}^{-1}$ ), while among haloacetonitriles monochloroacetonitrile (MCAN) and dichloroacetonitrile (DCAN) occurred at much lower concentrations. 1,1 Dichloroproponanone and 1,1,1trichloropropanone were at detectable levels after 7 days of retention, although they have been reported to decompose in short time (Nikolaou et al., 2001), which is an implication that their concentrations could have been higher just after chlorination, and then decreasing during the 7-d period due to their decomposition to chloroform. This could be also an explanation for the occurrence of relatively high chloroform concentrations even in samples from Omerli and Buyukcekmece waters with high bromide concentration.

\section{CONCLUSIONS}

The TTHMFPs varied seasonally in surface water resources for Istanbul. Due to relatively high TTHMs concentrations in the water treatment plant effluent attention must be paid to TTHMs concentration in the distribution network. The pre-oxidation with ozone as substitute to chlorine in Elmali water treatment plant significantly decreased TTHMs concentration in the effluent. Thus the upgrading of the Istanbul water treatment plants in terms of both ozone in place of chlorine (in preoxidation) and enhancing coagulation can improve TTHMs control.

The results obtained from Italian water resources showed that the level of TTHMFPs in raw water was high in the case of surface water, and after treatment it decreased by $35 \%$. The raw groundwater yielded much more lower TTHMFPs $\left(<100 \mu \mathrm{g} \mathrm{l}^{-1}\right)$ while the distribution of the species was different from surface to groundwater depending on raw water characteristics, in particular, TOC and bromide concentrations. 
Table 5. TTHMFPs and HAAs-FPs and chlorinated compounds detected in the chlorinated Istanbul and Salerno's raw water samples

\begin{tabular}{|c|c|c|c|}
\hline Concentration $\left(\mu \mathrm{g} \mathrm{I}^{-1}\right)$ & Buyukcekmece & Omerli & Alento \\
\hline \multicolumn{4}{|l|}{ THMs } \\
\hline Chloroform & 42.1 & 62.4 & 57.5 \\
\hline Dichlorobromomethane & 49.3 & 42.5 & 15.9 \\
\hline Dibromochloromethane & 65.8 & 23.6 & 2.2 \\
\hline Bromoform & 2.2 & $\mathrm{Nd}$ & nd \\
\hline \multicolumn{4}{|l|}{ HAAs } \\
\hline Monochloroacetic acid & 13.3 & 7.9 & 2.8 \\
\hline Monobromoacetic acid & 2.5 & 2.7 & 2.4 \\
\hline Dichloroacetic acid & 23.1 & 36.6 & 72.9 \\
\hline Bromochloroacetic acid & 8.1 & 7.4 & 5.2 \\
\hline Trichloroacetic acid & 19.7 & 41.4 & 137.7 \\
\hline Dibromoacetic acid & 2.4 & 1.2 & 0.8 \\
\hline Bromodichloroacetic acid & 8.7 & 9.3 & 3.6 \\
\hline Dibromochloroacetic acid & 12.1 & 10.6 & 9.2 \\
\hline Tribromoacetic acid & nd & nd & 8.4 \\
\hline Total & 89.9 & 117.1 & 243 \\
\hline \multicolumn{4}{|l|}{ Other volatile DBPs } \\
\hline Monochloroacetonitrile & 2.4 & 2.0 & 2.0 \\
\hline Dichloroacetonitrile & 3.5 & 3.4 & 3.9 \\
\hline Trichloroacetonitrile & nd & nd & nd \\
\hline Chloral hydrate & 69.2 & 78.1 & 61.3 \\
\hline 1,1-Dichloropropanone & 0.6 & 0.4 & 1.2 \\
\hline 1,3-Dichloropropanone & nd & nd & nd \\
\hline 1,1,1-Trichloropropanone & 0.7 & 0.7 & 0.9 \\
\hline Monobromoacetonitrile & 1.6 & 0.6 & 2.6 \\
\hline Dibromoacetonitrile & 1.1 & 0.9 & nd \\
\hline Bromochloroacetonitrile & nd & nd & 3.2 \\
\hline Chloropicrin & nd & nd & nd \\
\hline
\end{tabular}

n.d. not detected

The recent water samples taken from Omerli and Buyukcekmece (Istanbul) and Alento (Salerno) showed different THMs characteristics from the previous results. The measurement of HAAs and other volatile chlorinated compounds enhanced the basic knowledge to evaluate the water quality and the water treatment systems for the particular water resources. However, detailed measurements are necessary, in more samples from both present and other water resources as well as toxicity studies conducted in parallel, to evaluate the effect of raw water characteristics on the DBPs formation and their control.

\section{ACKNOWLEDGEMENTS}

The authors are gratefully to (i) Prof. R.M.A. Napoli for his suggestions, (ii) MIUR (Italian Ministry for Research and University and Instruction) and the NATO Grant [EST.CLG.980506], which funded in part this work, (iii) drinking water utilities for the collaboration in Salerno (ASIS, Pluriacque) and in Istanbul (ISKI) and (iv) Rosario Casale and Paolo Napodano for the technical assistance. 


\section{REFERENCES}

Amy G.L., Chadic P.A., Chowdhury Z.K. (1987), Developing model for predicting trihalomethane formation kinetics. J Am. Water Works Assoc., 70 (7), 89-97.

APAT (2003), Annual Environmantal Quality Data. http://www.sinanet.anpa.it/documentazione/Annuario2003/ indicea2003.htm.

AWWA, APHA, WEF (1998), Standard Methods for the Examination of Water and Wastewater, $20^{\text {th }} \mathrm{Ed}$. American Public Health Association/American Water Works Association/Water Environment Federation. Washington D.C., USA.

Bell-Ajy K., Abbaszadegan M., Ibrahim E., Verges D., LeChevallier M. (2000), Conventional and optimized coagulation for NOM removal. J Am. Water Works Assoc., 92 (10), 44-58.

Bekbolet M. and Ozkosemen G. (1996), A preliminary investigation on the photocatalytic degradation of a model humic acid. Wat. Sci. Tech., 33, 189-194.

Bekbolet M., Cecen F., Ozkosemen G. (1996), Photocatalytic oxidation and subsequent adsorption characteristics of humic acids. Wat. Sci. Tech., 34 (9), 65-72.

Chang C-Y, Hsieh Y-H, Hsu S-S, Hu P-Y, Wang K-H (2000), The formation of disinfection byproducts in water treated with chlorine dioxide. J Haz. Mat., B79, 89-102.

Gallard H. and Gunten U. (2002), Chlorination of natural organic matter: kinetics of chlorination and of THM formation. Wat. Res., 36, 65-74.

Krasner S.W., McGuir M.J., Jacangelo J.C., Patania N.L., Reagan K.M., Aieta E.M. (1989), The occurrence of disinfection by-products in US drinking water. J Am. Water Works Assoc., 81(8), 41-53.

Li J.W., Yu Z., Cai X., Gao M., Chao F. (1996), Trihalomethane formation in water treated with chlorine dioxide. Wat. Res., 30(10), 2371-2376.

Lilly P.D., Moore T.C., Pegram R.A. (1994), Comparative renal and hepatic toxicity of bromodichloromethane (BDCM) and chloroform $\left(\mathrm{CHCl}_{3}\right)$ following acute oral aqueous administration to rats. Toxicologist, 14, 280.

Nikolaou, A.D., Lekkas, T.D., Kostopoulou, M.N. and Golfinopoulos, S.K. (2001), Investigation of the behaviour of haloketones in water samples. Chemosphere, 44(5), 907-912.

Nikolaou A.D., Lekkas T.D., Golfinopoulos S.K., Kostopoulou M.N. (2002a), Application of different analytical methods for determination of volatile chlorination by-products in drinking water. Talanta, 56(4), 717-726.

Nikolaou, A.D., Golfinopoulos, S.K., Kostopoulou, M.N., Lekkas, T.D. (2002b), Determination of haloacetic acids in water by acidic methanol esterification-GC-ECD method. Wat. Res., 36, 1089-1094.

Official Journal of Italy (2001). D.Lgs 31/2001.

Official Journal of Italy (2003). DM December, 23, 2003.

Palacios M., Pampillon J.F., Rodriguez M.E. (2000), Organohalogenated compounds levels in chlorinated drinking waters and current compliance with quality standards throughout the European Union. Wat. Res., 34 (3), 1002-1016.

Reckhow, D.A., Singer, P.C., Malcolm, R.L. (1990), Chlorination of humic materails: by-product formation and chemical interpretations. Environ. Sci. Technol., 24 (11), 1655-1664.

Rizzo L., Belgiorno V., Meriç S. (2004), Organic THMs precursors removal from surface water with low TOC and high alkalinity by enhanced coagulation, Water Supply, 24(11), 103-111.

Rook J.J. (1974), Formation of haloforms during chlorination of natural waters. Water Treat. Exam., 23 (2), 234-243.

Selcuk H., Sene J.J. and Anderson M.A. (2003), Photoelectrocatalytic humic acid degradation kinetics and effect of $\mathrm{pH}$, applied potential and inorganic anions. J Chem Technol. Biotechnol., 78, 979-984.

Selcuk H., Guler H., Kacmaz S.E. (2004), Evaluation of water quality and supplies by using geographical information systems in Istanbul. Fres. Environ. Bull., 13 (9), 906-909.

Teuschler L.K. and Simmons J.E. (2003), Approaching DBP toxicity as a mixtures problem. J Am. Water Works Assoc., 95(6), 131-138.

USEPA. (1998), National primary drinking water regulations: disinfectants and disinfection byproducts; final rule Final Rule Fed. Reg., 63/241/69478.

USEPA (2002), Drinking Water Standards and Health Advisories. EPA 822-R-02-038, Office of Water, U.S. Environmental Protection Agency, Washington, DC. 
Villanueva C.M., Kogevinas M., Grimalt J.O. (2003), Haloacetic acids and trihalomethanes in finished dirinking waters from heterogeneous sources. Wat. Res., 37, 953-958.

Von Gunten, U. (2003), Review: Ozonation of drinking water: Part II. Disinfection and by-product formation in presence of bromide, iodide or chlorine. Wat. Res., 37(7), 1469-1487. 